\title{
残胃肉腫の臨床的検討
}

兵庫医科大学第 2 外科（主任：伊藤信義教授）
石 川
羊

\section{CLINICAL STUDY OF SARCOMAS OF THE REMNANT STAMACH}

Yoshio ISHIKAWA, Hitoshi AIOI, Masamichi MATSUMOTO, Takehira YAMAMURA, Tokuro KUSUNOKI and Nobuyoshi ITO The Secon Department of Surgery, Hyogo College of Medicine

(Director: Prof. Nobuyoshi ITO)

残胃肉腫はごく稀な疾患であり，60歳，男性で胃潰禓による広範囲胃切除後23年目の

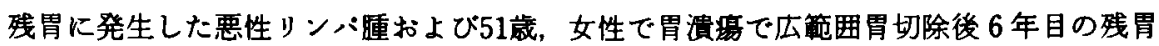
に発生した悪性リンバ腫の自験 2 症例を含む本邦報告16例について詳細に臨床像を検討 した，病理組織学的分類は悪性リン八腫が12例と高頻度で，平滑筋肉腫 3 例，悪性神経 䩗腫 1 例であった。男女比は $4: 1$ と男性に多く，平均年龄は55.9藏であった。一方，原 先患として胃潰瘍症例を多く認め，これら症例のすべてに幽門側胃切除が施行され，再 建方法は Billroth I 法がやや Billroth II 法より多くみられた。初回手術後の経過年数は 10カ月から23年におよんでおり，平均8.8年であった。臨床症状上，残胃肉腫に特異的な すのはなく，上腹部痛 $(64.2 \%)$, 体重減少 $(50.0 \%)$ が多くみられた。衒前に診断可能

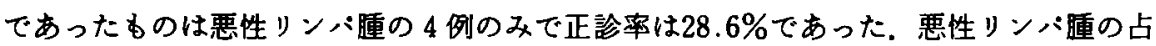
居部位は吻合部，断端部に63.6\%と過半数に認められた。開腹術は14例がうけており残 胃全摘術12例，胃空腸吻合術 1 例，単開腹術 1 例であり，その予後は残胃全摘術をらけ た12例中11例が生存している。自験例の 3 年 6 カ月を含め残胃の内腫とはいえ根治的切 除がなされれば十分な延命が期待できるすので, 残胃癌る含め胃切除後の follow up の 重要性を示唆した。

\section{綪百}

胃切除後の残胃にみられる悪性腫瘍の大多数は癌で あり, 残胃癌, 再発胃癌などの名称で呼ばれ比較的経 験するか，残胃に発生した肉尰に関する報告は極めて 稀である。最近，著者らは胃潰晹手術後23年目と 6 年 目の残胃に発生をみた悪性リンバ腫の 2 例を経输し本 邦報告例14例をあわせて残胃肉腫の臨床像を解析検討 した.

\section{症例}

症例 1.60葴, 男性, 農業

主訴：心窩部痛。

既往歴：37歳時, 胃漬湯で広範囲胃切除術, 59藏時, 椎間板へルニフで手術をらけた。

家族歴：姉が胃癌で死亡.
現病歴：昭和54年 1 月上旬上り食後に心富部痛，呕 気が続き近医を受診，胃透視，内視鏡検查を5け，胃 粘膜下腫場の题いで昭和54年 2 月 27 日当科へ紹介入䟚 となった。

入院時現症：体格栄養中等度, 眼眕結膜に軽度奢血 をみた．表在リンハ節は触知せず。心肺に異常なく， 上腹部正中に手術痗痕を認めるほか肝, 脾, 腫瘤は蜰 知せず。直腸指診で Douglas 窩に異常なし。

入院時検査所見：尿，便異常なし，赤血球数 $365 \times$ $10^{4}, \mathrm{Hb} 10.9 \mathrm{~g} / \mathrm{dl}$, 白血球数 3,400 . 肝機能検査正常. 免疫グロプリン正常. $\alpha$-Fetoprotein, CEA ともに異常 なし（表 1)。

胃X線所見：残胃噴門大弯側に壁外性と思われる圧 排所見と胃底部から吻合部にかけて粗造な粘膜を持つ 
衰 1 入院㭙検查所見（症例 1）

\begin{tabular}{|c|c|c|c|c|}
\hline \multicolumn{2}{|c|}{ RBC } & $365 \times 10^{4}$ & T.P. & $5.969 / \mathrm{d} \ell$ \\
\hline \multicolumn{2}{|l|}{$\mathbf{H b}$} & $10.9 \mathrm{~g} / \mathrm{d} \ell$ & Alb & $3.39 \mathrm{~g} / \mathrm{d} \ell$ \\
\hline \multicolumn{2}{|l|}{ Ht } & $32.0 \%$ & ZTT & 8. $80 \mathrm{U}$ \\
\hline \multicolumn{2}{|l|}{ Plt. } & $24.1 \times 10^{4}$ & TTT & $1.01 \mathrm{U}$ \\
\hline \multicolumn{2}{|l|}{ Ret. } & $4 \%$ & Bil-T & $0.62 \mathrm{mg} / \mathrm{d} \ell$ \\
\hline \multicolumn{2}{|c|}{ WBC } & 3400 & $A / G$ & 1.3 \\
\hline \multicolumn{2}{|c|}{ Mbl } & $0 \%$ & GOT & $24 \mathrm{KU}$ \\
\hline \multicolumn{2}{|c|}{ pro } & $0 \%$ & GPT & $15 \mathrm{KU}$ \\
\hline \multirow{4}{*}{$\mathbf{N}$} & My & $0 \%$ & Alp & $2.8 \mathrm{BLU}$ \\
\hline & Met & $0 \%$ & LDH & $214 \mathrm{U}$ \\
\hline & st & $2 \%$ & LAP & $109 \mathrm{GRU}$ \\
\hline & seg & $40 \%$ & BUN & $21.2 \mathrm{mg} / \mathrm{d} \ell$ \\
\hline \multicolumn{2}{|c|}{ Lym } & $54 \%$ & $\alpha-F$ etoprotein & $2.5 \mathrm{ng} / \mathrm{m \ell}$ 以下 \\
\hline \multicolumn{2}{|c|}{ Mo } & $2 \%$ & CEA & 1. Ong/nlLL下 \\
\hline \multicolumn{2}{|c|}{ Eo } & $2 \%$ & IgG & $1880 \mathrm{mg} / \mathrm{d} \ell$ \\
\hline \multirow{2}{*}{\multicolumn{2}{|c|}{ Ba }} & $0 \%$ & $\operatorname{Lg} A$ & $166 \mathrm{dg} / \mathrm{d} \ell$ \\
\hline & & & $\operatorname{IgM}$ & $124 \mathrm{mg} / \mathrm{d} \ell$ \\
\hline
\end{tabular}

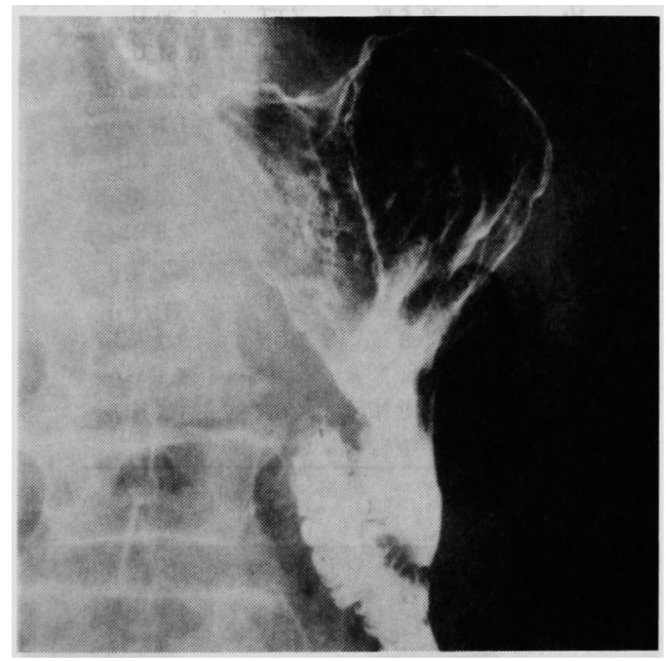

写真 1 症倒 1. 切除用の胃 X線所見：残胃噴門大弯 側に壁外性の圧排所見がみられる

肥大した破壁を認め，胃壁全体は軟かく伸展性は良好 であった（写真 1 ）.

内視鏡検查：噴門大弯側に肥大した般壁がみられ， 表面は易出血性で erosion を伴い一部に粘膜下腫場の 存在を思わせる隆起がみられた，小弯側の粘膜は凹凸 不整で erosionが多発しており胃底部に連続してい た。病変部は全体に軟らかく伸展は良好で多彩な病像 を呈していることから悪性りンパ腫を疑った（写真 $2)$.

生検の組像は Group IVで悪性リンバ腫が疑われ た.

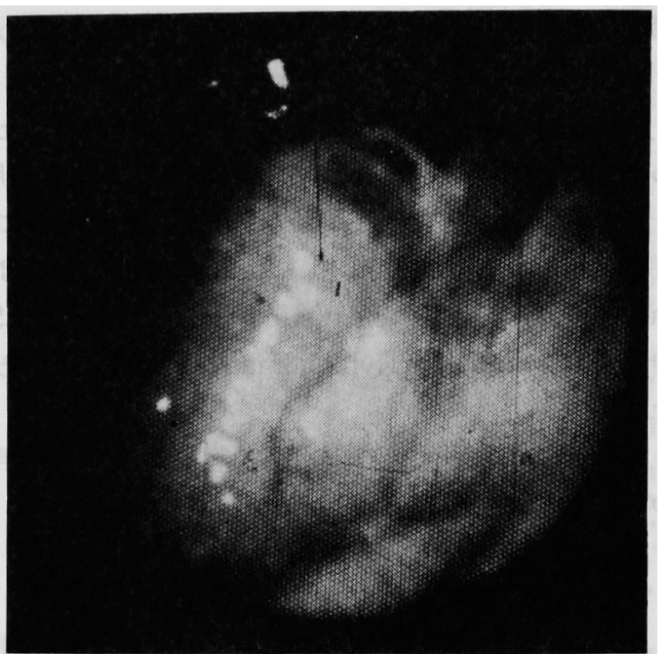

写真 2 症例 1 。切除胃の内視鏡所見：軟らかく腫大 した解壁とその表面には erosionがみられる。

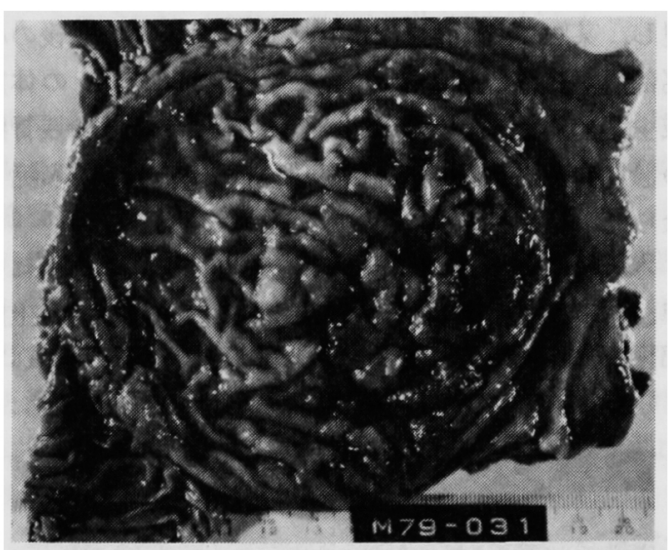

写真 3 症例 1. 切除胃肉眼所見：軟らかく畽大した 壁が脳回転状を呈し，発赤, erosionを伴なってい る。佐野 ${ }^{19)}$ の分類による巨大船壁型に属する。

手術所見：Billroth II 法結腸後で再建された牫胃に は明らかな腫瘤は触知されず，肝転移，将䝢潤，腹 膜播種などは認めず，胃癌取扱い規約によるNo. 2, No.10のリンバ節がそれぞれ拇指頭大，大豆大に腫大 し転移がみられた。残胃を全摘し $R_{3}$ のリンハ節廊清を 施行した。再建は $\rho$ 型の Roux-en·Y 法により行なっ た.

切除胃肉眼所見：写真 3 は残胃を小弯切開したもの で，大弯側の畽大した䏢暲は軟かく脳回転状を呈し， 発赤, erosion を多数伴って, 一部に粘膜下腫䔽様の隆 起がみられたが潰瘍形成はなかった。本症例の肉眼形 
態は佐野19のの分類による巨大船笠型に属するるので あった（写真 3）.

病理組織所見：腫㻛組織は中型リンバ球を主体とす る大小のリンハ球が混在しており，粘膜から固有筋䅉， 一部浆膜下組織にまで漫潤がみられる。腫湯組織には 明瞭な沪胞結節が存在し, Rappaport 分類では, mixed, lymphocytic and histiocytic, nodular で, LSG 分類では, follicular lymphoma, mixed typeであっ た（写真 4 ）.

術後経過は良好で術後29日目に軽快退院し，3年 6 カ月再発の徵なく健在である。

症例 2.51歳, 女性, 教師.

主訴：心富部痛, 体重減少。

既往歴：43歳時, 肝资. 45歳時, 胃溃境で厇範团胃 切除術をらけた。

家族歴：特記すべきことなし。

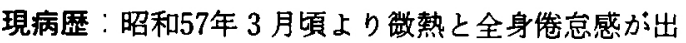
現し，某医で筫血を指摘された. 4 月頃より食後の心 窝部痛が持続するよらになり，2 カ月間で $5 \mathrm{~kg} の$ 体重 減少を認めたため近医で上部消化管精査をらけ残胃癌 の診断のもとに昭和57年 6 月 17 日当科へ紹介入院と なった。

入院時現症：身長 $149 \mathrm{~cm}$, 体重 $39 \mathrm{~kg}$ 。眼䀫結膜に筫 血. 表在リンパ節は触知せず。心肺に異常なく, 上腹 部正中に手術瘦痕を認め，心窝部に小児頭大の硬い可

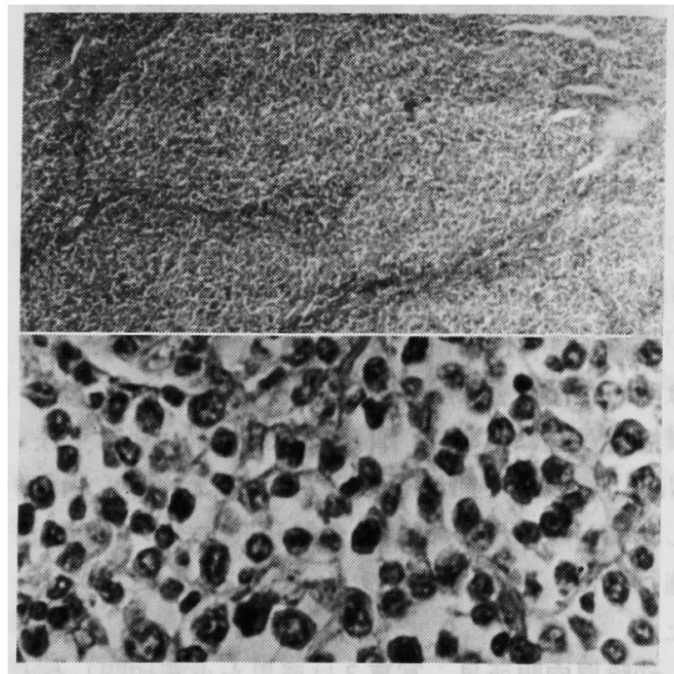

写高 4 症例 1. 病理組䋨楅本 H.E. 杂色上段 $(\times 40)$, 下段 (X400) : mixed lymphocytic and histiocytic, nodular (Rappaport) follicular lymphoma, mixed type (LSG)
動性のない腫瘤を触知. 弁は右鎖骨中線上で1.5横指通 大をみたが，脾は触れず。直腸指診では Douglas 窝に 異常を認めず。

入院時梌查所見：尿異常なし，便潜血グアヤック法 (H). 赤血球数 $316 \times 10^{4}, \mathrm{Hb} 9.5 \mathrm{~g} / \mathrm{d} \mathrm{d}, \mathrm{Ht} 28.6 \%$, 血 血球数 3,400 , 肝機能検查で LDH 1,329U と高值を示 ナはかは異常なし、 $\alpha$-Fetoprotein, CEA とも異常なし （表 2 ).

胃X線所見：残胃小弯を中心に噴門部から吻合部に 扣けて㳭い惯瘍形成を伴 5 Borrmann 3 型の病変を 認め,輸入脚は腫場により圧排をらけていた（写真5).

表 2 入院時検查所見（症例 2)

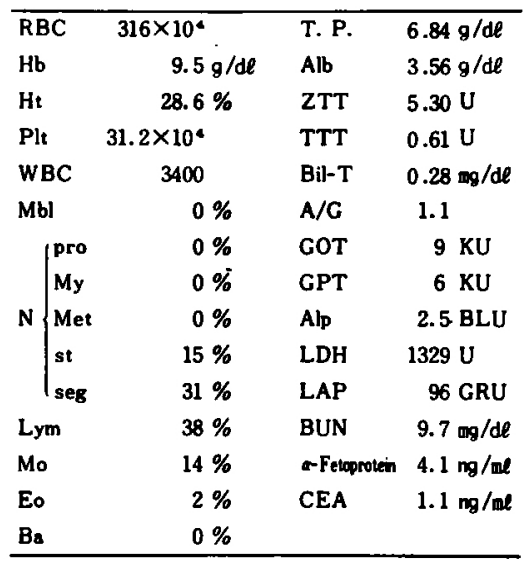

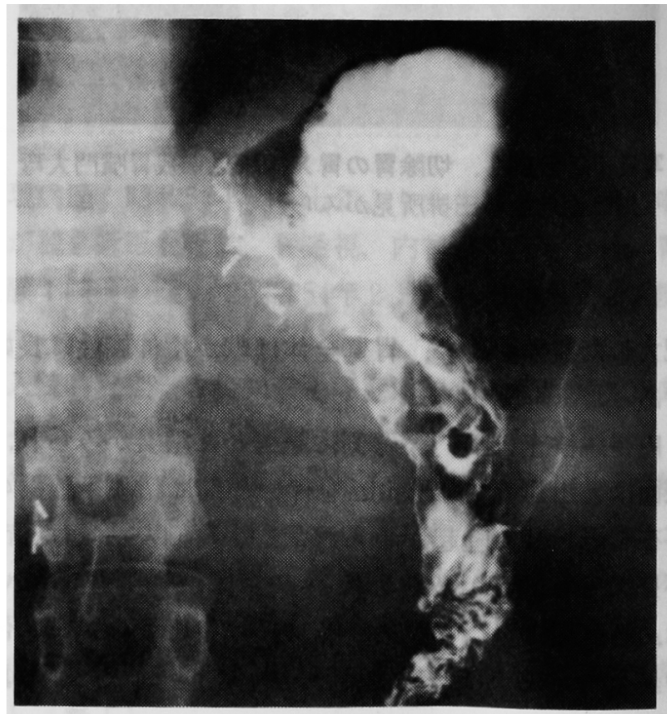

写基 5 症例 2. 切除胃の胃X緗所見：残胃小弯断端 部に Borrmann 3 型病变を認める. 輸入脚は腫就に より閉塞している. 


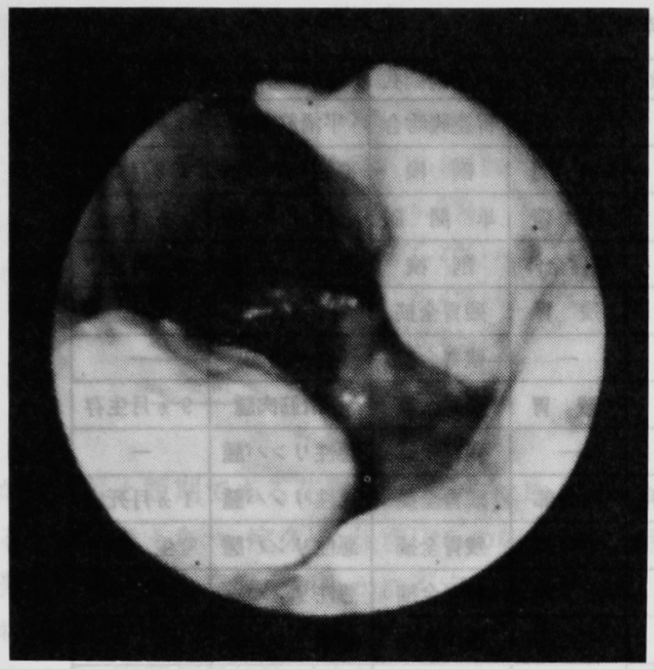

写重 6 症例 2. 切除胃の内梘鏡所見：小弯に厚い ラード状の白苔で被れた深い謴瘍がみられる。

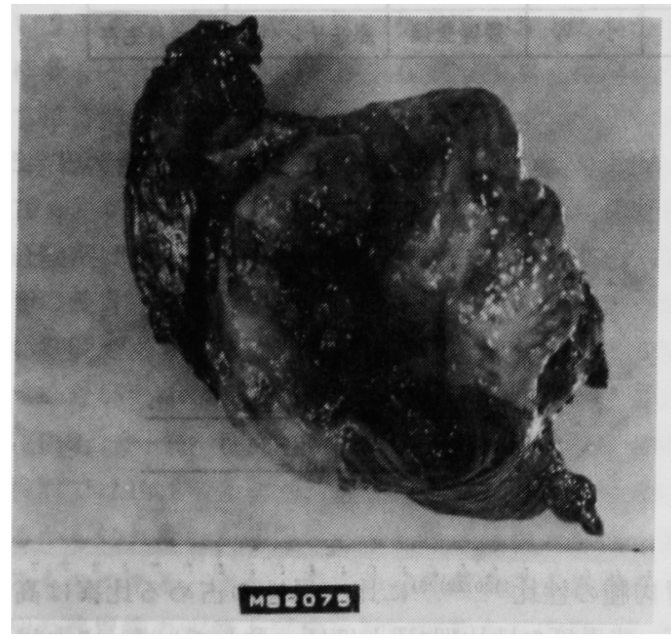

写共 7 症例 2. 切除胃肉眼所見：腫瘦は小弯を中心 に壁外性発育を示し中心部に深い、漬煌形成を伴い， 肝に穿通していた，佐野 ${ }^{19)}$ の分類による決潰型に属 する.

内視鏡所見：小弯を中心に噴門から吻合部を越えて 厚いラード状の白苔で被れた凹凸不整の深い潰湯形成 を伴 5 Borrmann 2 型の病変がみられ, 輸入脚は周提 によって閉塞していた（写真 6 ).

残胃癌を疑い生検を施行したが，いずれるGroup II で悪性の所見は得られなかった。

手術所見：上腹部 L字切開で開腹。䂝胃小弯より壁 外性発育を示した超手拳大の腫瘤が肝左葉, 塆に浸潤 していた，肝転移，腹膜播種は認めなかった。腫瘍と

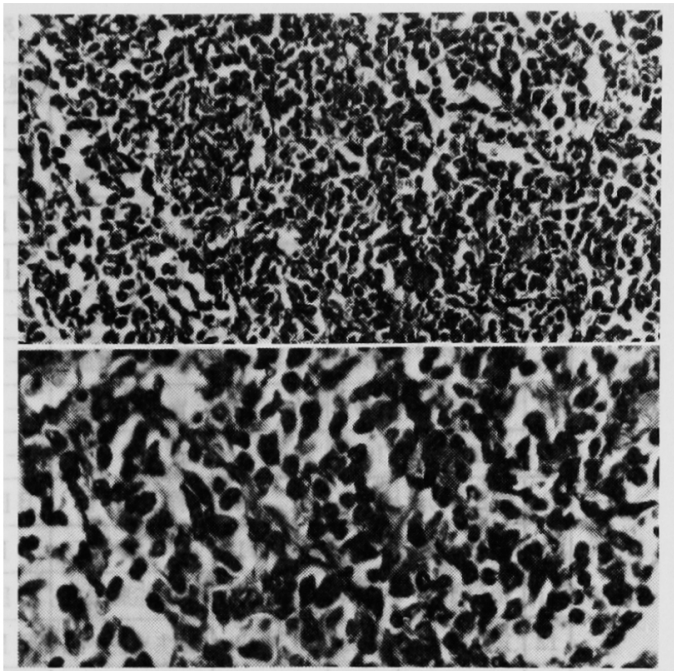

写真 8 症例 2. 病理組䄉標本. 上段 $(\times 100)$, 下段 $(\times 200)$ : diffuse, lymphocytic, poorly differentiated type (Rappaport) diffuse lymphoma, medium-sized cell type (LSG)

共に腲体尾, 脾, 肝外側区域を一塊として牫胃全摘術 を施行した。転移りンパ節は第 1 群のみで $\mathrm{R}_{2}$ の廓清を 施行した. 再建は $\rho$ 型の Roux-en-Y法で行なっった。

切除胃肉眼所見: 残胃小弯断端部を中心に前後壁に わたって $10 \times 11 \mathrm{~cm}$ の深い漬瘍がみられ，潰場底は凹 凸を示し厚いラード状の白苔で被れていた，健常粘膜

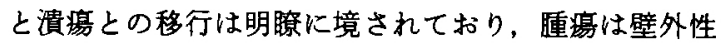
に発育を示し肝に穿通していた，佐野199分類による 決潰型に属するものであった（写真7）.

病理組織所見：核小体が明瞭で厚い核膜を有した中 等大の細胞がびまん性に増殖しており，大部分は粘膜 層より浆膜下層にまで浸潤し，一部䐙，肝組織に及ん でいた。組織像は mlaignant lymphomaで, Rappaport 分類では, diffuse, lymphocytic, poorly differentiated type で, LSG分類では, diffuse lymphoma, medium-sized cell typeであった（写真 8 ).

術後経過は良好であり，2 月月現在化学療法中であ る.

考 案

原発性胃肉腫の報告は，1967年に大井'が93施設に おける非癌性胃腫瘍の集計的調查をおこない257例を 報告している。しかし，残胃にみられる肉腫に関して の報告は少なく，欧米では1952年にKyrle らが胃潰 瘍に上る胃切除後18年目の残胃に発生した細網肉腫症 
表 3 残胃肉原の本報告例

\begin{tabular}{|c|c|c|c|c|c|c|c|c|c|c|}
\hline & 帮告 者 & 年度 & 性 年合 & 原疾意 & 再等法 & 怪週年数 & 発生部位 & 再手術術式 & 病理琵断 & 予 哟 \\
\hline 1 & 田中ほが & 1968 & 男 53 & 十二指䐎溃禺 & B I & 8 年 & 残 胃 & 胃空晹吻合 & 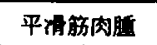 & 5ヶ月死亡 \\
\hline 2 & 山原 ${ }^{51}$ & 1972 & 58 & 早 神 & B I & 11年 & 惯 Py & 剖 梌 & 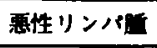 & 1 カ月死亡 \\
\hline 3 & 花田はが & 1972 & 67 & 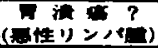 & B I & 10 力月 & 小 码 & 草网 成 & 惩性リンバ丨 & 1 力月死亡 \\
\hline 4 & 守田ほか” & 1974 & 53 & 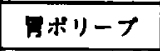 & B D & 7 年 & 瑆用全体 & 剖 湌 & 恶性リンパ & 2 カ月死亡 \\
\hline 5 & 县田任が & 1975 & 56 & 十二指腈洪的 & - & 14 年 & 磯 & 残用全推 & 平消筇肉照 & - \\
\hline 6 & 小川はか” & 1976 & 43 & 消化管出血 & - & 11 力月 & - & 残周全描 & 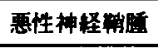 & - \\
\hline 7 & 三井ほか & 1977 & 57 & 月 洪 蛅 & - & 4 年 & 牫 & 残骨全揞 & 平消第肉䏦 & 9 力月生存 \\
\hline 8 & 池田 $^{\text {II) }}$ & 1979 & - & 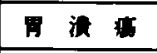 & - & 9 年 & - & 残胃全描 & 斆性リンパ造 & - \\
\hline 9 & 堀江はが & 1979 & 62 & 7 港 & B I & 3 年 6 力月 & 吻合部 & 理同全描 & 哥性リンパ㥀 & 1 力月死亡 \\
\hline 10 & 素䦌はが & 1979 & 男 71 & 同淟 & B I & 13年 & 吻合部 & 残南全揞 & 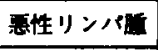 & 生 存 \\
\hline 11 & 須労ほが & 1980 & 52 & 十二指滕暴的 & B II & 16年 & 小 & 残閒全描 & 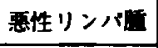 & 生 存 \\
\hline 12 & 室久ほが & 1980 & 48 & 悪性リンパ遺 & B I & 10年 & 小焚 & 残用全推 & 㯖性リンパ锤 & 生 存 \\
\hline 13 & 加䒼( & 1981 & 50 & 早期㓩唐 & - & 9 年 & 伆合部 & 残用全揞 & 悪性リンパ有 & - \\
\hline 14 & 後萑はが & 1981 & 57 & 悪性リンパ㯰 & B I & 5 年 & 啨 $\mathrm{FH}$ & 残周全搭 & 䭴性リンハ任 & 1年4 力月生主 \\
\hline 15 & 数宝 & 1980 & 60 & 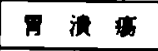 & B II & 23年 & 残 & 残周全澫 & 悪性リンパ煎 & 3年6 力月生存 \\
\hline 16 & 数室例 & 1982 & 51 & 用 筷 & B I & 6 年 & 小西 & 残间全揞 & 悪性リンパ & 2 力月生存 \\
\hline
\end{tabular}

例を報告し，また，1958年，Côté ら ふ3が十二指腸謴瘍切 除後 2 年目の胃体部後壁にみたリンバ肉腫と胃潰瑒切 除後 8 年目の胃空腸吻合部後壁に発生した血管内皮腫 の 2 症例を報告している. 本邦では1968年, 田中”が残 胃癌症例中, 残胃の平滑笳肉属症例の報告をして以来, 著者らの 2 症例を含め16例を数えるにすぎない（表 3 ).

\section{1. 頻度わよU゙分䅡}

胃の悪性腫瘍に対する胃肉腫の頻度は，諸家の報 告1)6191 25)によると0.5〜4.8\%である. 第38回胃癌研

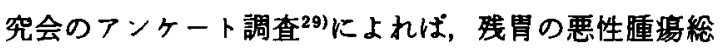
数613例が集計されており，5ち癌腫を除く悪性畽瘍は 9 例あり，その頻度は1.5\%であった。

残胃肉庫16例の病理組織学的分類（表 4) は，悪性 リン八腫12例 $(75.0 \%)$, 平滑筋肉腫 3 例 $(18.8 \%)$, 悪性神経鞴腫 1 例 (6.3\%) で, 墨性リンバ腫と平滑筋 肉腫の比は 4:1となり大井"), 暒谷 ${ }^{20)}$, Marshall ${ }^{25)}$ の報 告とほぼ一致する。

\section{2. 年龄, 性.}

不明の 1 例を除く15例の検討では，50歳台（48～71 葴）に最も多く，その平均年龄は55.9嵅であった。こ れら原発性胃肉腫の平均年龄120122127228) とほぼ一致す るが，残胃癌の平均年龄30311 よりやや高龄であった。

性別では男12例, 女 3 例で, 男女比は4：1と原発性

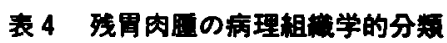

\begin{tabular}{|c|c|}
\hline 組 織 分 類 & 症 例 \\
\hline 悪性リンパ脂 & 12 例 $(75.0 \%)$ \\
\hline 平滑筋肉腫 & 3 例 $(18.8 \%)$ \\
\hline 悪性神経酳嗹 & 1 例 $(6.3 \%)$ \\
\hline 計 & 16 例 $(100 \%)$ \\
\hline
\end{tabular}

胃肉腫の性比 ${ }^{120122225)}$ に比べ男性の占める比率は高い が，残胃癌の性比30)-32) とはぼ一致している。これは残 胃癌と同様に消化性漬瘍で胃切除をうける対象が男性 に多いといら結果であろう。また，疾患別に男女比を みると悪性リンパ腫5：1, 平滑節肉腫 $2 ： 1$ と特に悪性 リンパ畽に男性の占める比率が高かった 22).

3. 原疾患 (表 5 ).

胃潰湯 7 例，十二指腸潰暍 3 例，胃ポリーブ，消化 管出血，胃癌がそれぞれ1例，覀性リンバ腫 3 例で原 疾患が良性のものは11例であった。胃潰湯と十二指腸

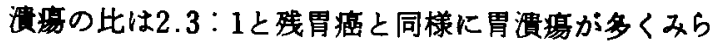
れたが30)31)，手術対象症例中胃謴場の占める率が高く， 原疾患と残胃肉腫発生との関係を述べことはできな い.しかし, 悪性リンパ腫では癌腫に比べ多発する傎 向が強く ${ }^{1222)}$ ，原疾患が悪性リンパ腫でありしかす释 
衰 5 原疾患

\begin{tabular}{|c|c|}
\hline 原 疾 急 & 症 例 \\
\hline 胃 溃 瘦 & 7例 $(43.8 \%)$ \\
\hline 十二指腸溃准 & 3 例 $(18.8 \%)$ \\
\hline 胃ポリープ & 1例 $(6.2 \%)$ \\
\hline 消化管出血 & 1例 (6.2\%) \\
\hline 胃 癌 & 1例 ( $6.2 \%)$ \\
\hline 悪性リンパ腫 & 3例 $(18.8 \%)$ \\
\hline 計 & 16 例 ( $100 \%)$ \\
\hline
\end{tabular}

過が10カ月と短期である花田ら

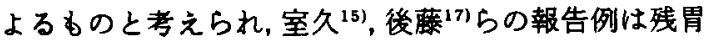
再発，異時性多発発生を明らかに否定しえない。

\section{4. 原疾患手衍衍式.}

すべてに幽門側胃切除が施行されており，それら再 建法は記載のある11例についてみると Billroth I 法 6 例, Billroth II 法 5 例と残胃癌に Billroth II 法が多い とい5諸家の報告30) 32) と異なり Billroth I 法がわず かに多くみられたが，対象検索症例が少なく傾向につ いては言明しえない。

\section{5. 初回手術後の経過年数.}

10カ月から23年にわたってみられ，最長例は著者ら の経験例であった。平均経過年数は8.8年と教室の山下 ら ${ }^{30)}$ の残胃癌平均経過年数 11.1 年に比べるとかなり短 かい期間でありこれら初回病変を非肉腫症例に限定 していないためで遺残，再発，異時性多発と考えられ る花田 ${ }^{6)}$, 小川 ${ }^{91}$, 室久 ${ }^{15)}$, 後藤 ${ }^{(7)}$ らの症例を除く 12 例 の検討では10.2年となり，発生条件による多少の差は あるかる知れないが残胃癌の平均経過年数とほぼ一致 するすのである，また，著者らは残胃肉腫も教室の山 下 ${ }^{30)}$ の残胃癌の定義と同様に初回病变を非肉腫とし10 年以上を経過した症例に限定すべきことを提言しそう すれば該当症例はわずかに 5 例であり，残胃に発生す る肉尰の臨床的解析がり徹底して行いらると考え ろ.

\section{6. 病悩期間.}

推定可能な11例について検討すると 1 カ月から6力 月の病悩期間を持ち，その平均は4.0力月である。これ

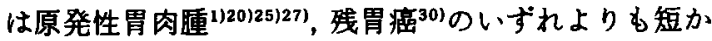
い期間であった。

\section{7. 酶床症状 (表 6 ).}

記載の明らかな14例について険討すると心窝部痛, 季肋部痛，空腹時痛などの上腹部痛が 9 例 $(64.2 \%)$ と過半数にみられ，体重减少 7 例 $(50.0 \%)$, 食思不振
表 6 残胃肉近の臨床症状（14例）

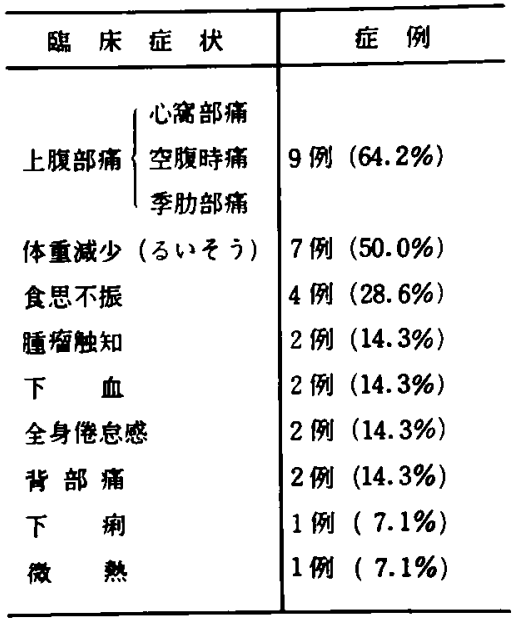

表 7 残胃肉怔の術前診断 (14例)

\begin{tabular}{|c|c|}
\hline 䛦断 名 & 症 \\
\hline 胃 肉 腫 & 4 例 (28.6\%) \\
\hline 胃 & 6 例 $(42.9 \%)$ \\
\hline 腫 & 2 例 (14.3\%) \\
\hline 陰影欠損 & 1 例 $(7.1 \%)$ \\
\hline 肝 & 1 例 $(7.1 \%)$ \\
\hline 計 & 14例( $100 \%)$ \\
\hline
\end{tabular}

4 例 (28.6\%)，その他腫瘤触知，下血，全身倦急感， 背部痛がそれぞれ 2 例，下㢉，教熱が 1 例にみられた。 これら症状は原発性胃肉的とはほ同槏であ

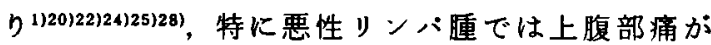
$81.8 \%$ と高頻度にみられ 20128)，また下血の 2 例はいず れも平滑筋肉腫症例であった25)26)，たた残胃癌の臨床 症状 ${ }^{30131) 33)}$ と明らかに相異するところは呕吐, 膨满感, 絔下困難などの通過障害としての症状を呈したものが 1 例あみられなかった点である ${ }^{25)}$ 。これら腫瘍の持つ 特異性として癌腫に比べ悪性リンパ腫では胃壁の伸展 性が比較的保たれ6)，食道へあまり浸潤しない24とい 5結果と考えられる。

8. 術前診断 (表 7).

記載の明らかな14例中胃肉庫と術前に診断されたる のはわずか 4 例で，胃癌と診断されたもの6 例，腫痬 とのみ記載されたもの 2 例, 陰影欠損としたもの 1 例， 肝癌と誤認されたるの 1 例で良性疾患と誤診されたも のはなかった，術前の正診率は14例中 4 例（28.6\%） 
表 8 残胃肉厔の占居部位（14例）

\begin{tabular}{|c|c|c|c|}
\hline 部位 & 悪性リンバ成 & 平滑管肉迁 & 計 \\
\hline 噴 門 & 2 & & 2例(14.3\%) \\
\hline 胃 & 1 & 3 & 4 例 $(28.6 \%)$ \\
\hline 小丝断端 & 4 & & 4例 $(28.6 \%)$ \\
\hline 吻 合 部 & 3 & & 3 例 $(21.4 \%)$ \\
\hline 残胃全体 & 1 & & 19 (7.1\%) \\
\hline
\end{tabular}

表 9 残胃肉居の手術々式 (14例)

\begin{tabular}{|c|c|c|c|}
\hline & 残胃全摘術 & 胃空陣响合街 & 単開腹術 \\
\hline 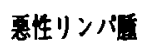 & 9 & & 1 \\
\hline 平滑筇肉题 & 2 & 1 & \\
\hline 悪性模经期通 & 1 & & \\
\hline 計 & 12例 & 1 例 & 1 例 \\
\hline
\end{tabular}

ですべて悪性リンバ重症例であり，内視鏡的に1例， 生検によるすのが 3 例であった。原発性胃肉腫の術前 の正診率は文献的に9.3－68.8\% ${ }^{122234335)}$ と大差があ る. 生検，細胞診の確立で従来より正診率の向上がみ られ，春日井ら ${ }^{22}$ は生検により80\%，細胞診で $90 \%$ の 正診率を報告しているか，病期，施設，検査の組み合 せ，検者などによる差，また，術後胃といら悪条件て の診断の困難さは当然であるが，肉腫の形態学的病理 組織学的特徵を十分に考慮した生検法の確立か肝要と 思われる243(4) 36)。

9. 占居部位（表 8 ）.

切除胃を噴門，残胃，小弯断端，吻合部に分類し記 載のある14例について検討した，噴門 2 例（14.3\%）, 残胃 4 例 $(28.6 \%)$ ，小弯断端 4 例 $(28.6 \%)$ ，吻合部 3 例(21.4\%)，残胃全体にみられたものが 1 例であっ た．全体としてはいずれの部位にも発生しており明ら かな特徵は認められないが，疾患別にみると悪性リン 八腫は吻合部，小弯断端部に発生したものが63.6\%と 過半数に認められ，平滑筋肉腫はいずれる残胃にみら れ，大井 ${ }^{12}$ ，梶谷 ${ }^{20)}$ の報告のごとく胃上部大弯側に発生 するものと一致した。

10. 手術（表 9 ), 転移（表10）。

14例に開腹術が施行されており残胃全摘術12例，5
表10 残胃肉原（覀性リンパ盾）の深達度および転移 ( 9 例)

\begin{tabular}{|c|c|c|c|}
\hline 深達度 & 症 例 & 転 移 & 症 例 \\
\hline 粘膜下層 & 2 2例(22.2\%) & リンパ篗坛稳 & 5 例 $(55.6 \%)$ \\
\hline 獎 膜 & 3例 (33.3\%) & 肝 転 移 & 1例(11.1\%) \\
\hline 他侁器浸洞 & 4 例 (44.4\%) & 腹膜播種 & 0 例 \\
\hline
\end{tabular}

ち肝, 膵, 脾, 横行結腸などの他葴器の合併切除がな されたすのが 6 例であった。その他，胃空腸吻合術 1 例，単開腹術 1 例で全体としての切除率は $75 \%$ と根 谷 ${ }^{201}$ の原発性胃肉腫切除率77.8\%よりわずかに低い が, 残胃癌の切除率 ${ }^{301311} に$ 比しかなりの高率であった。

転移，深達度について記載のある9例の悪性りン: 尰症例についての検討では，粘膜下層までにとどまる 早期悪性リンバ腫が 2 例にみられ，浆膜におよぶすの 3 例，他藏器への漫潤をみたるの 4 例であった。リン ：節転移は 5 例に認め。肝転移は 1 例のみであったが， 腹膜への播種性転移を示したものは 1 例むなく，楃 谷 $^{20)}$ ，矢田 ${ }^{231}$ らの述べているごとく奨膜面浸潤が明ら かであっても腹膜播種に到るものは少なく、これらの 因子が残胃癌に比べ切除率を結果的に高くしたるのと 思われた。

\section{1. 予後}

原発性胃肉腫患者は胃癌に比へ，一般的に経過は棌 慢で悪液質や全身哀弱などの出現も遅く，予後良好と する報告2012427) むある。予後の判明している12例につ いてみると5例 (41.7\%) が死亡しており，その平均 生存期間は 2 力月と極めて不良であった。これら死亡 症例は平滑筋肉腫が 1 例，他の 4 例は悪性リン八睡で あり，開腹術をらけたものは 3 例で 2 例は非手術例で あった。逆に残胃全摘術が施行され予後の判明してい る 8 例（悪性リンパ腫 7 例, 平滑筋肉腫 1 例）につい てみると, 死亡は悪性リンバ腫の 1 例のみで術後 1 カ 月目の心不全による他病死であった。すなわち，癌䛻 に比一腹膜播種が少ないなどにより根治的切除がなさ れる可能性も高く，十分な延命が期待できるすと思

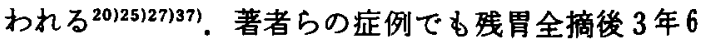
力月再発の徽むなく健在であり，再手術が悪条件に なっても積極的な外科的療法が延命につながるすのと 推測される.

12. 発生要因.

残胃癌と同様に不明ではあるが，1）切除胃では物 
理的, 化学的刺激。 状態がおこる。これらの炎症が間質におよびリンパ慮 胞の増生が持続的過鄱におこることによってッンが網 内系の悪性化につながる可能性は否定できない、38339). 今回，調査した残胃悪性リンパ畽の5ち $63.6 \%$ と過半 数が吻合口，断端部に関係して発生して拉り，吻合口 炎, 断端炎がなんらかの発生要因に関与している可能 性を示唆するるのかす知れない，2）RLH (reactive lymphoreticular hyperplasia）を胃潰惶と誤認して胃 切除がなされ，その断端に遺残したすのが長期にわた り刺敨をらけることによって悪性化する.3）悪性リン 泪重は多発する傾向があり ${ }^{116)}$ ，残胃再発るしくは異時

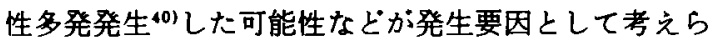
れる.

\section{赫語}

教室で経験した残胃肉腫 2 例と本邦報告14例の集計 的検討を試みた。

1）病理組織学的分類は悪性リンバ腫12例, 平滑筋肉 腫 3 例，悪性神経䩗腫 1 例であった。

2）年龄は48歳から71歳で平均55.9歳，男女比は 4 1と男性に多くみられた。

3）原疾患は胃謴瘍 7 例，十二指腸謴瘍 3 例，胃术 リープ，消化管出血，胃癌がそれそれ 1 例。悪性リン ：腫が 3 例で，すべてに幽門側胃切除がなされ，その 再建法は Billroth I 法が Billroth II 法よりやや多かっ た.

4）初回手術後経過年数は 10 カ月から 23 年におよび 平均経過年数は8.8年であった。

5）臨床症状は上腹部痛が $64.2 \%$, 体重减少 $50.0 \%$, 思不振が $28.6 \%$ にられ，それら病愊期間は平均 4.0 カ月と短かかった。

6）術前に正診されたものは悪性りンバ腫の 4 例 (28.6\%)で，内視鏡的診断 1 例，生検組織診断による すのが 3 例であった。

7）占居部位では悪性リンパ腫は吻合部, 断端部に発 生したものが多くみられた。

8）14例に開腹術が施行され，残胃全摘術12例でその 切除率は75\%と高率であった。

9）予後は著者らの 3 年 6 力月生存症例を含め根治 的切除がなされたすのは良好であった。

残胃肉腫の定義として残胃癌同様良性原疾患術後 10 年の経過が必要であることを提言し，これによって遗 残，再発，異時性多発病変の多くを除外することで残 胃肉盾の臨床病理学的解析がより単純化しらると考え
る.

\section{引用文献}

1）大井 実, 三穂乙実，伊東 保他：非癌性胃腫韵 一全国93主要医療施設加らの集計的調査一, 外科, 29 : 112-133, 1967.

2) Kyrle, P. and Wild, H.: Über magenstupfkarzinome. Zbl. Chir., 77 : 1481-1488, 1952.

3) Côté, R., Dockerty, M.B. and Cain, J.C.: Cancer of the stomach after gastric resection of peptic ulcer. Surg. Gyne. \& Obstet., 107: 200 -204, 1958.

4）田中 隆, 高橋右一, 岩本英男他：残胃癌の症例, 外科, $30: 1460-1464,1968$.

5）山際裕史：残胃の悪性睡場の2剖検例，内科，29： 352-356, 1972.

6）花田弘義，赤岩正男, 斉藤敏比古他：原発性胃肉腫 について，臨床外科，27:1153-1161，1972.

7）守田知明, 増田哲彦, 中村俊吾他：残胃悪性畽湯の 2在例，広島医学，27：1197-1200，1974。

8）恩田光憲，小林誠一郎，神原 宣他：切除胃に発生 した Leiomyosarcoma の1例，日消病会誌，72： 1052, 1975.

9）小川喜輝，藤井陖宏，佐々木信博他：残胃巨大腫愓 の1例, 厇島医学、29：103，1976.

10）三井俊明, 松木 清, 田辺征六他：巨大な残胃平滑 筋肉腫の 1 例，日臨外会誌，38：111-112，1977。

11）池田 公：残胃に発生した細綱肉謴の1治験例，日 外会誌，80：80-81，1979.

12）堀江 泰, 恵谷 敏, 大同禮次郎他：残胃に発生し 胃結腸瘦を併発した 細網肉腫の1例。外科，41： 834-836, 1979 .

13）春間 堅，田中一也，末永健二他：残胃に原発した 細網肉腫の1例。胃と腸，14：973-976，1979。

14）須藤蜳章, 白羽 誠, 河村正生他：残胃恶性リンパ 尰の1例，臨床外科，35：1769-1772，1980.

15）宝久敏三郎, 武藤良弘, 脇 慎治他：胃切除後 10 年, 残胃に再発した悪性リン八畽とその細胞診, 日 臨細胞会誌，19：699，1980。

16）加藤義昭, 兼城覧明, 西川久和他：異時性三重複早 期悪性腫瘍（胃・直腸・残胃）の1例，日消病会誌， $78: 1146,1981$.

17）後藤信婎，後藤和夫，横地 真他：残胃に5年後再 発した胃細網肉重の1例，胃と腸，16：523-526， 1981.

18）相生 七, 宮村 忍, 嵯峨山徹他：残胃癌の4例と, 残胃悪性リン八゙尾1例の経験，日臨外会誌，41： 
1117-1118, 1980.

19）佐野量造：胃疾患の臨床病理，医学書院， 257-283, 1974.

20）棍谷 鏢，渡辺 弘，高木国夫：原発性胃肉腫につ いて, 癌の臨床, $6: 141-151,1960$ 。

21）佐野量造, 広田映五, 下田忠和他：胃肉隀の病理。 胃と腸, 5:311-322, 1970.

22）春日井達造, 加藤 久, 坪内 実他：胃肉厙一内視 鏡診断を中心に一，胃と腸，5：287-299，1970.

23）矢田比古, 佐々木明, 榎本正満他：原発性胃肉尰 手征例の予後についての険討，臨床外科，36： $965-969,1981$.

24) 山形䧶一：臨床消化器病講座. 胃疾患, 金原出版, 276-293, 1976.

25) Marshall, S.F. and Meissner,W.A.: Sarcoma of the stomach. Ann. Surg., $131: 824-837,1950$.

26) Thompson, H.L. and Oyster, J.M. : Neoplasms of the stomach other than carcinoma. Gastroenterol., $15: 185-243,1950$.

27) Snoddy, W.T.: Primary lymphosarcoma of the stomach. Gastroenterol., 20:537-553, 1952.

28）常松 匠, 徳山英太郎：胃肉尰の臨床上の特異性 について, 24:1540-1546, 1969.

29）第38回, 胃癌研究会、フンケート“残胃の癌”のまと め, 東京, 1982.

30）山下忠義, 多滜芳樹，稲積亘雄他：残胃癌の統計的
覾宗一本邦症例106例を中心として一，外科，34： $719-725,1972$.

31）島律久明，小城略一郎。保阪茂文他：残胃初発癌症 例に肉する榙討. 日消外会誌, $12 ： 713-723,1979$.

32）山形敉一，增田久之，三田正紀他：胃断端癌, 内科, $14: 1344-1360,1964$.

33）藤田吉四郎，伊藤一二，三輸 他：残胃の癌27例 の外科的検討，外科， $31: 919-926,1969$.

34）㭘山護，福地創太郎，望月孝規：胃覀性リンバ腫 の内視鏡診断と生㭲, 胃と腸, 8:165-176, 1973.

35）豊田龍生, 神山隆一, 望月孝規他：胃覀性リンバ腫 の生検診断, 胃と腸, $16: 413-419 ， 1981$.

36）信田重光, 光口祥一，横田腾正他：胃肉腫の細胞 診, 胃之腸, $16: 407-412,1981$.

37) Frazer, J.W.: Malignant lymphomas of the gastrointestinal tract. Surg. Gyne. \& Obstet., $108: 182-190,1959$.

38）中村恭一：胃悪性リンバ弫の病理組織学的研究, とくに組織発生について，癌の臨床，10： $163-176,1964$.

39）山際裕史：胃のリンパ網内系の变動一胃の悪性リ ンバ腫の発生, 医学のあゆみ, $78 ： 701 一 703,1971$.

40）小陶堅一郎, 島津久明, 保阪茂文他：胃悪性リンハ 腫の異時重複発生一胃とその他の部位に括ける発 生からの考察, 医学のあゆみ, 114:441-443, 1980. 